Kastamonu Eğitim Dergisi
$\begin{aligned} & \text { Kastamonu Education Journal } \\ & \text { Ocak 2020 Cilt:28 Sayı:1 } \\ & \text { kefdergi.kastamonu.edu.tr }\end{aligned}$

\title{
Suriyeli Ortaokul Öğrencilerinin Türk Eğitim Sistemindeki Yaşantılarına İlişkin Bir Değerlendirme ${ }^{1}$
}

\section{An Evaluation Regarding Experiences In Turkish Education System Of Syrian Middle School Students}

\section{Öz}

\author{
Selvi DEMiR² \& Yılmaz DEMiR ${ }^{3}$
}

Bu araştırmanın amacı, Suriyeli ortaokul öğrencilerinin Türk eğitim sisteminde öğrenci olma deneyimini ve bu deneyimi etkileyen ortam veya durumları değerlendirmektir. Nitel araştırma yöntemlerinden fenomenoloji deseniyle yürütülmüş olan bu araştırmanın verileri, yüz yüze görüşme yoluyla yarı yapılandırılmış görüşme formu kullanılarak elde edilmiştir. Araştırma kapsamında, 2017-2018 eğitim öğretim yılında Kilis ilindeki devlet okullarından birinde öğrenim görmekte olan 8 Suriyeli öğrenci ile görüşme yapılmıştır. Araştırmadan elde edilen bulgulara göre Suriyeli öğrencilerin Türkiye'de eğitim gördükleri okullarda ayrımcılığa tabi tutulmadıkları, dışlanmadıkları ve derslerde göz ardı edilmedikleri belirlenmiştir. Suriyeli öğrenciler, bulundukları ortamdan memnun olmanın verdiği haklılıkla geleceklerini Türkiye'de görmekte, ülkelerine dönme konusunda isteksiz görünmektedir. Araştırmada Suriyeli öğrencilerin sorun yaşadığı tek faktörün arkadaş faktörü olduğu, Türk akranlarından beklenen ilgi ve kabullenmeyi görmedikleri belirlenmiştir.

Anahtar Kelimeler: eğitim yaşantıları, suriyeli ortaokul öğrencileri

\section{Abstract}

The aim of this research is to evaluate the experience of being a student in Turkish Education System of Syrian Middle School students and set of surroundings or situations affecting this experience. Data of this study handled with phenomenology pattern which is from one of the methods of qualitative research are obtained as a means of face-toface meeting by using semi-structured interview form. Within the scope of research, we have an interview with 8 Syrian students receiving education in one of the state schools in Kilis in 2017-2018 Academic year. According to results acquired from research, it is determined that Syrian students aren't subjected to discrimination, they aren't alienated, and they aren't ignored during lessons in the schools they study in Turkey. Syrian students are reluctant to turning back to their country, justifiably, they are pleased with environment they live and so they see their future in Turkey. In the study, it is identified that the only problem Syrian students face is making friends and they don't attract the expected attention and espousing from their Turkish peers.

Keywords: educational experiences, syrian secondary school students

\footnotetext{
${ }^{1}$ Bu çalışma, Akdeniz Üniversitesinde 2-5 Mayıs 2018 tarihinde gerçekleştirilen V th International Eurasian Educational Research Congress'de sözlü bildiri olarak sunulmuştur.

${ }^{2}$ Kilis 7 Aralık Üniversitesi, MREF, Türkçe ve Sosyal Bilimler Eğitimi Bölümü, Kilis, Türkiye, https://orcid.org/0000-0002-7043-7414

${ }^{3} 15$ Temmuz Şehitleri Ortaokulu, Kilis, Türkiye, https://orcid.org/0000-0001-5477-1300

Atıf / Citation: Demir, S. ve Demir, Y. (2020). Suriyeli Ortaokul Öğrencilerinin Türk Eğitim Sistemindeki Yaşantılarına İlişkin Bir Değerlendirme . Kastamonu Education Journal, 28(1), 456-467. doi:10.24106/kefdergi.3663
} 


\section{Extended Abstract}

Introduction: When body of literature is examined, it is encountered that there are various researches for Syrian students' education at a national and an international level. On this subject, some of the studies done in Turkey show that training Syrian children and Turkish children all together causes sundry problems. This detection is mostly reflected with teacher and director perspective but students' perspective is ignored. It isn't encountered to a research representing Syrian middle school students' own perspectives in regard to their experiences in Turkish Education System. Therefore, it is purposed to specify Syrian students' substantial positive or negative emotions and thoughts, problems, prospectively expectations within the scope of the experience of being a students in Turkish Education System and to reveal setting or situations affecting this experience in this study. This study is thought that it will subsidize to studies in related body of literature and steer coming researches to a different channel.

Method: In this study, qualitative data collection methods such as observation, interview and document analysis are used. Phenomenologic pattern is used in the research. Within the scope of research, we have an interview with 8 Syrian students receiving education in one of the state schools in Kilis in 2017 - 2018 Academic year. Participants must speak Turkish and be a student actively so they are designated with criterion sampling. In the study, interview method which is one of the qualitative data collection methods is used. Semi-structured interview questions used in the research are prepared based on viewing observation and body of literature. In order to test expediency of questions, it is checked with three experts and to test lucidness, it is interviewed with three middle school students. The interviews took approximately between $15-20$ minutes and they are done face to face with participants. With their permission and confirmation, the interviews are saved with recorder. The questions are asked to Syrian students. Which experiences did you face with this phenomenon and which environment or situation did affect your experience? So as to present findings to the readers in a regulated and interpreted way, descriptive analysis method is used.

Results: Findings obtained from researches are headlined like that: "Findings for Syrian Middle School Students' Experiences with Their Families", "Findings for Syrian Middle School Students' Experiences with Turkish Students", "Findings for Syrian Middle School Students' Experiences with Teachers and School Administration" and "Findings for Syrian Middle School Students' Experiences with Their Education". The results obtained show that families speaking Turkish can help their children with their courses and homework but the others cannot. So, some Syrian students have disadvantages about this issue. On the other hand, research results reveal that Syrian students' families support their children's education and although they can't speak Turkish, that is not problem for them, they go to schools to take care of their children. Another result shows that Syrian students don't get enough attention and adoption from their Turkish peers. On the other side, some Syrian students are adopted by their Turkish peers but they are the ones speaking Turkish and successful students. Syrian students mostly want to spend time with their Turkish peers but they spend time between each other. The reasons of this request are especially learning Turkish easily, some Syrian students' bad behaviors and their incuriousness to courses. According to some other findings obtained from research, considerable majority of Syrian students state that their teachers behave them well, their teachers treat them as they treat Turkish students, their teachers teach lessons with respect to they can understand, and their teachers make an effort to attach Syrian students to the lessons. Considerable majority of participants think it is because they are good at lessons and they can speak Turkish well. So, teachers don't discriminate among students. In addition, the research shows that school administration also don't discriminate and exclude Syrian students from Turkish students. According to the results of the study, it shows that Syrian students speaking Turkish don't have any problems with expressing their thoughts and emotions to both their fellow and opposite sex. However, others have problems about this issue. Besides, it is clear that all of the participants are determined to go to school regularly and they are disposed to go to a university. Moreover, research results exhibit that Syrian Middle School students are reluctant to turning back to their country, justifiably, they are pleased with environment they live and so they see their future in Turkey.

Suggestions: At the conclusion of the study, it is suggested that the views of Syrian students and their families should also be taken into consideration directed to Syrian students' education experiences in academic researches, Syrian students and Turkish students' collusive activities at intramural and extra scholastic should be focused in order to provide cultural amalgamation, decisions should urgently be made aimed at aftermath of Syrian students seeing their future in Turkey and education should be arranged according to this situation, and lastly, awareness education should be given at all education institutions, especially the ones having Syrian students, and in society with a view to prevent preconception, sternness, and conflicts. 


\section{Giriş}

Bireyin davranışlarında kendi tecrübesi yoluyla istendik değişmeyi oluşturma süreci (Ertürk, 1975) olarak tanımlanan eğitim, bireylerin sosyal yaşamda yerlerini almaları, gerekli bilgi, beceri ve anlayışları elde etmeleri, kişiliklerini geliştirmeleri açısından oldukça önemlidir. Dolayısıyla birçok toplumda başta okulların ilk kademeleri olmak üzere birçok kademesinde eğitim öğretim faaliyetleri ücretsiz olarak devlet tarafından yürütülmektedir. Türkiye' de de ilköğretim zorunlu ve devlet okullarında ücretsizdir. Bu uygulamanın amacı Çınar'a (2008) göre temel bir insan hakkı olmasının yanı sıra ilköğretimin toplumsal yararının diğer öğretim kademelerinden fazla olmasıdır. Zorunlu olmasının altında yatan neden ise; toplumun üyeliğine hazırlanan tüm bireylerin bilmesi gereken asgari bilgi, tutum, beceri ve davranışların kazandırıması gereğidir. Öte yandan bu çok kapsamlı faaliyetin yürütüldüğü eğitim öğretim ortamlarında çeşitli sorunlarla karşılaşmak kaçınılmazdır. Özellikle son yıllarda dünya ölçeğinde yaşanan önemli sorunlardan biri, artan bir ivmeyle göç yoluyla bir ülkeden bir diğerine yapılan kitlesel nüfus hareketleri sonucu göçe maruz kalan çocukların karşı karşıya kaldıkları eğitim sorunudur. Böyle bir durumda göçle gelen çocukları eğitmek, bir yandan çocukların hakkı iken öte yandan ev sahibi ülkelerin kültürel ve sosyal yaşamı ortak paydalarda buluşturması adına zorunlu bir hal almaktadır. Bu açıdan düşünüldüğünde göç sonucu gelen çocukların eğitiminin taşıdığı önem daha net bir görünüme kavuşmaktadır.

Türkiye, konumu itibariyle bölgedeki yeni gelişmeler ve gösterdiği sosyal ve ekonomik gelişimler nedeniyle son yıllarda yoğun bir şekilde hem göç alan hem de göçmenlere geçiş alanı oluşturan bir ülke konumundadır. 2014 yılında, tahmini olarak 19,5 milyon kişi olan dünyadaki toplam mülteci sayısının 1,6 milyonu Türkiye'de barınmıştır. Buna göre yaklaşık \% 8,21'lik oranla Türkiye, bu yıldan itibaren dünyanın en büyük mülteci barındıran ülkesi konumundadır (United Nations, 2016). Kuşkusuz bunda, 2011 yılında Suriye'de yaşanan iç savaş etkili olmuştur. Nitekim 2011 yılında Türkiye'de hiçbir Suriyeli sığınmacı, mülteci veya geçici koruma altında kişi bulunmazken 2012 yılında 14237; 2013 yılında 224655; 2014 yılında 1519286; 2015 yılında 2503549; 2016 yılında 2834441; 2017 yılında ise 3426786 kişi geçici koruma altındadır. 2018 yılına gelindiğinde ise Türkiye'deki Suriyelilerin sayısı 3622366 kişiyi bulmuştur. Bu bağlamda 27.12.2018 tarihi itibariyle Türkiye'de 143452'si geçici korunma merkezinde, 3478914'ü geçici koruma merkezi dışında olmak üzere toplam 3622366 Suriyeli yaşamaktadır. Bölgedeki istikrarsızlık sürdükçe Türkiye'nin giderek daha çok uluslararası mülteci veya sığınmacı meselesiyle karşı karşıya kalacağı kaçınılmazdır. Türkiye'de Suriyelilerin en fazla yaşadıkları iller İstanbul, Şanlıurfa, Hatay, Gaziantep, Adana, Mersin, Bursa, İzmir, Kilis ve Konya'dır. Toplam nüfusunun \% 46'lık oranına denk gelen Suriyeli nüfusuyla Kilis, bu iller içerisinde en dikkat çekenidir (İçişleri Bakanlığı, 2018). Bu veriler, Kilis ilinin bu araştırmada örneklem olarak seçilmesinin isabetli olduğunu göstermektedir.

Suriye'de devam eden savaş, günümüzde karşı karşıya olunan en büyük insani krizin oluşmasına sebep olmaktadır (Aktekin, 2017). Suriye'deki savaştan kaçan nüfusun (3622366 kişi) önemli bir bölümünü çocuklar (1726701 kişi) oluşturmaktadır. Suriyeli çocukların eğitim gibi en temel halklarından birinden yoksun bırakılması, kuşkusuz bu krizin daha da derinleşmesine sebep olacaktır. Öte yandan her çocuğun yaşama hakkı gibi en temel haklarından biri olan eğitim hakkı, hem ulusal hem de uluslararası çeşitli belgelerle güvence altına alınmıştır. Sözgelimi, Birleşmiş Milletler Çocuk Haklarına Dair Sözleşmesi gereğince "taraf devletler çocuğun eğitim hakkını ve bu hakkın fırsat eşitliği temeli üzerinde tedricen gerçekleştirilmesi görüşünü kabul etmektedir" (Madde 28) maddesi çocuğun eğitim hakkını küresel ölçekte koruma altına almaktadır. Dolayısıyla gerek vicdanen gerekse uluslararası hukuktan doğan bir sorumluluk çerçevesinde, Türkiye'ye sığınan birçok Suriyeli çocuk eğitim öğretim sürecine dâhil edilmiştir.

Suriyelilerin eğitim hakkına erişimleriyle ilgili düzenlenen "2014/21 Sayılı Yabancılara Yönelik Eğitme ve Öğretme Hizmetleri Genelgesi" ile resmi kaydı bulunan Suriyeli çocukların, Milli Eğitim Bakanlığı'na (MEB) bağlı okullarda ya da Suriyelilere yönelik oluşturulmuş Geçici Eğitim Merkezleri'nde (GEM) eğitim alabilecekleri ifade edilmektedir (Ertaş ve Çiftçi Kıraç, 2017). Böylece MEB, geçici koruma altında bulunan eğitim öğretim çağındaki bu çocukların nitelikli bir eğitim öğretim hizmetinden faydalanarak hızla toplumsallaşabilmelerini sağlayabilmek için çalışma başlatmıştır (Aktekin, 2017). GEM dışında kalan geçici koruma altındaki Suriyeli çocukların, Türkiye'deki eğitime erişimine katkı sağlamak ve Türk eğitim sistemine entegrasyonundaki çabalarında MEB'e destek vermek amacıyla gerçekleştirilen "Suriyeli Çocukların Türk Eğitim Sistemine Entegrasyonunun Desteklenmesi Projesi" (Pictes, 2017) gibi projelerle çok sayıdaki Suriyeli çocuğun, eğitim öğretim faaliyetleri desteklenmektedir. Suriyeli çocuklara sunulan eğitim hizmetleri; kamp içi eğitim, kamp dışı eğitim ve Suriyelilerin açtığı özel okullar olmak üzere üç 
başlıkta toplanabilir. Ayrıca kamp dışında verilen eğitim, geçici eğitim merkezleri ve devlet okullarında sürdürülmektedir (Emin, 2016).

Türkiye'de yıllara göre Suriyeli çocuklara yönelik yapılan eğitim öğretim faaliyetlerine bakıldığında, her eğitim öğretim yılında bir önceki yıla göre önemli oranda Suriyeli öğrencinin eğitim hayatına dâhil edildiği görülür. Ayrıca kaç çocuğun hangi eğitim kurumlarında öğrenim gördüğü Tablo 1'de verilmiştir. Bu verilere göre Suriyeli öğrencilerin bir taraftan okullaşma oranının arttığı görülürken diğer taraftan Suriyeli öğrencilerin artan sayıyla resmi okullarda Türk öğrencilerle birlikte eğitime devam etkileri görülmektedir.

Tablo 1: Yıllara göre Suriyeli öğrencilerin eğitim durumları

\begin{tabular}{lllll}
\hline & $\mathbf{2 0 1 4 - 2 0 1 5}$ & $\mathbf{2 0 1 4 - 2 0 1 5}$ & $\mathbf{2 0 1 6 - 2 0 1 7}$ & $\mathbf{2 0 1 7 - 2 0 1 8}$ \\
\hline Resmi Okullara Kayıtlı & 40000 & 62357 & 201505 & 387849 \\
Resmi Okullara Kayıtı Öğrenci \% & $\% 17,39$ & $\% 20,03$ & $\% 40,91$ & $\% 63,55$ \\
GEM Kayıtlı Öğrenci & 190000 & 248902 & 291039 & 222429 \\
GEM Kayıtlı Öğrenci \% & $\% 82,61$ & $\% 79,97$ & $\% 59,09$ & $\% 36,45$ \\
Toplam Öğrenci Sayısı & 230000 & 311259 & 492544 & 610278 \\
Okul Çağına Gelmiş Nüfusu & 759000 & 834842 & 833039 & 976200 \\
Okullaşma & $\mathbf{3 0}$ & $\mathbf{3 7}$ & $\mathbf{5 9}$ & $\mathbf{6 2 , 5 2}$ \\
\hline
\end{tabular}

Kaynak; MEB, 2018

Göç İdaresi Genel Müdürlüğü’nün Eylül 2017 verilerine göre sayıları 976200 olan Suriyeli eğitim çağındaki nüfusun kademeli olarak MEB'e bağlı resmî okullara kaydedilmesi çalışmaları devam etmektedir. MEB'e bağlı resmî okullarda (GEM dışındaki okullarda) kitlesel göçle gelen 333913 geçici koruma altındaki Suriyeli ve 39807 Iraklı olmak üzere toplam 373720 öğrenci Türkçe müfredatla eğitim görmektedir. Tablo 2 incelendiğinde, 21 ilde 318 geçici eğitim merkezinde tamamı Suriyeli olmak üzere 222429 öğrenci, yoğun Türkçe öğretimi temel olmak kaydıyla eğitim öğretim görmektedir. Bu verilere göre ortaokulda okullaşma oranı 50,44\% iken lisede bu oran \% 23,93'e düşmüştür (MEB, 2018). Dolayısıyla eğitim kademesi ilerledikçe okullaşma oranının düştüğü söylenebilir.

Tablo 2: Eğitim kademelerine göre Suriyeli öğrencilerin eğitim durumları

\begin{tabular}{llllrl}
\hline Eğitim Kademesi & Resmi Okullar & GEM & Toplam & Çağ Nüfus & Oran \% \\
\hline Okul Öncesi (5 Yaş) & 29457 & 7091 & 36548 & 93791 & 38,97 \\
ilkokul (6-9 Yaş) & 236624 & 137680 & 374304 & 351231 & 106,57 \\
Ortaokul (10-13 Yaş) & 83065 & 54548 & 137613 & 272819 & 50,44 \\
Lise (14-17 yaş) & 24570 & 22718 & & & \\
Açılk ve diğer liseler & 14133 & 392 & 61813 & 258359 & 23,93 \\
Toplam & $\mathbf{3 8 7 8 4 9}$ & $\mathbf{2 2 2 4 2 9}$ & $\mathbf{6 1 0 2 7 8}$ & $\mathbf{9 7 6 2 0 0}$ & $\mathbf{6 2 , 5 2}$ \\
\hline
\end{tabular}

Kaynak; MEB, 2018

Suriyeli öğrencilerle ilgili yapılan alanyazın taramasında ulusal ve uluslararası düzeyde birçok çalışma yapıldığı görülmektedir. Suriyeli öğrencilerin bulunduğu okullarda özellikle öğretmen ve yöneticilerin görüşlerine göre karşılaşılan sorunlarla ilgili çok sayıda çalışma (Saklan ve Erginer, 2017; Tösten, Toprak ve Kayan, 2017; Sakız, 2016; Sarıtaş, Şahin ve Çatalbaş, 2016; Mercan Uzun ve Bütün, 2016; Levet ve Çayak, 2017; Taşkın ve Sıldıroğlu, 2016; Emin, 2016) bulunmaktadır. Ayrıca Suriyeli öğrencileri Türk eğitim sistemine entegre etmede GEM'lerin rolünü değerlendirmek amacıyla başta GEM yöneticilerinin olmak üzere bürokrat ve STK görüşlerine göre yapılan araştırmaya (Aras ve Yasun, 2016) ulaşılmıştır. İlgili diğer bir çalışma Özer, Komsuoğlu ve Ateşok (2016) tarafından yürütülen Türkiye'de, Suriyeli çocukların eğitimi ile ilgili kamu politikaları inşa sürecindeki sorunları ve çözüm önerilerini merkeze alan bir araştırma projesinin verileri üzerine inşa edilmiştir. Alpaydın (2017), çalışmasında Türkiye'deki Suriyeli çocuklara yönelik eğitim politikalarını analiz ederken; Büyükikiz ve Çangal (2016) çalışmalarında Suriyeli öğrencilerle ilgili 25 Mart 2013'te başlayan, 3 Haziran 2016 yılında tamamlanan dört proje hakkında bilgi vermektedir. Seydi (2014), Suriyeli çocukların eğitim sorunlarının çözümüne yönelik gelişmeleri incelerken; Ertaş ve Çiftçi Kıraç (2017), Türkiye'nin Suriyeli çocuklara yönelik uyguladığı eğitim politikalarını ve çalışmaları değerlendirmektedir. Baltaci (2017) ise Suriyeli öğrencilerle yaptığı görüşmeyle Türkiye ve Almanya'daki Suriyeli göçmen öğrencileri karşılaştırarak, öğrencilerin girişimcilik eğilimleri ve kariyer beklentileri üzerine bir çalışma yapmıştır. Yapılan alanyazın taramasında genellikle Suriyeli çocukların Türk çocuklarıyla birlikte eğitime katılmalarının birtakım sorunların sebebini oluşturduğu ve bu durumun öğretmen, yönetici ve velilerin bakış açısıyla yansıtıldığı görülmektedir. Buna karşın bizzat Suriyeli öğrencilerin Türk eğitim sistemindeki yaşantılarına ilişkin kendi bakışlarının ele alındığı bir çalışmaya rastlanmamıştır. 
Dolayısıyla bu araştırmanın amacı, Suriyeli öğrencilerin Türk eğitim sisteminde öğrenci olma deneyimi kapsamında var olan olumlu, olumsuz duygu ve düşüncelerini, sorunlarını, geleceğe dair beklentilerini belirlemek ve bu deneyimi etkileyen ortam veya durumları ortaya koymaktır. Bu araştırmanın, ilgili alan yazındaki araştırmalara destek sağlayacağı gibi yapılacak çalışmaları farklı bir kanala yönlendireceği de düşünülmektedir.

\section{Yöntem}

Araştırmada nitel araştırma yöntemi kullanılmıştır. Nitel araştırma, gözlem, görüşme ve doküman analizi gibi nitel veri toplama yöntemlerinin kullanıldığı, algıların ve olayların doğal ortamda gerçekçi ve bütüncül şekilde ortaya konmasına yönelik nitel bir sürecin izlendiği araştırmalardır (Yıldırım ve Şimşek, 2016). Türkiye'deki MEB'e bağı okullarda öğrenim görmekte olan Suriyeli ortaokul öğrencilerinin eğitim öğretim yaşantılarına odaklanan bu araştırmada olgubilim (fenomenoloji) deseni tercih edilmiştir. Kaynağını felsefe ve psikolojiden alan olgubilim deseni, farkında olunan ancak derinlemesine ve ayrıntılı bir anlayışa sahip olunmayan olgulara odaklanan, tecrübe edilen fenomenleri nasıl bir araya getireceği üzerine yoğunlaşan dolayısıyla deneyimin temel yapısını betimleyen bir araştırma desenidir (Creswell, 2017; Yıldırım ve Şimşek, 2016; Patton, 2014; Merriam, 2013).

\section{Katılımcılar}

Pek çok nitel araştırmaya göre, fenomenoloji üç ila on kişinin deneyimlerini incelemeyi içerir (Creswell, 2017). Bu araştırma, 2017-2018 eğitim öğretim yılında Kilis il merkezindeki bir devlet okulunda öğrenim görmekte olan 8 Suriyeli ortaokul öğrencisiyle yürütülmüştür (Tablo 1). Katılımcılar, amaçlı örnekleme yöntemlerinden ölçüt örnekleme kullanılarak belirlenmiştir (Yıldırım ve Şimşek, 2016). Buna göre katılımcıların, araştırmaya katılmaya istekli ve gönüllü olma, ortaokulda aktif olarak öğrencilik yapma ve kendilerini ifade edebilecek yeterlikte Türkçeyi bilme ölçütleri dikkate alınmıştır. Katılımcıların isimleri görüşme sırasına göre Ö1, Ö2, Ö3, ... şeklinde kodlanmıştır.

Tablo 3. Katılımcıların demografik özellikleri

\begin{tabular}{crccc}
\hline Katılımcı & Cinsiyeti & Yaşı & Sınıf Düzeyi & Türkiye'de Yaşadığı Süre \\
\hline Ö1 & Erkek & 12 & 6 & 6 yıl \\
Ö2 & Kadın & 12 & 6 & 7 yıl \\
Ö3 & Kadın & 12 & 6 & 3 yıl \\
Ö4 & Kadın & 12 & 6 & 3 yıl \\
Ö5 & Erkek & 11 & 6 & 7 yıl \\
Ö6 & Kadın & 13 & 7 & 6 yıl \\
Ö7 & Erkek & 11 & 5 & 5 yıl \\
Ö8 & Kadın & 11 & 5 & 5 yıl \\
\hline
\end{tabular}

\section{Veri Toplama Yöntemi}

Fenomenolojik çalışmalarda veri toplama, fenomen ile ilgili deneyimi olan bireylerle derinlemesine görüşmeler kullanılarak toplanmaktadır (Creswell, 2016). Bu araştırmada nitel araştırmalardaki temel veri toplama araçlarından biri olan görüşme yöntemi kullanılmıştır. Yüz yüze yapılan görüşmelerde yarı yapılandırılmış görüşmeler ile veriler toplanmıştır. Yarı yapılandırılmış görüşme tekniği, "görüşmenin büyük bir kısmını açıklığa kavuşturacak esnek, çoğunlukla açık uçlu ve ek sorularla katılımcıların algıladığı dünyayı kendi düşünceleriyle anlatmasını sağlar" (Merriam, 2013). Araştırmada kullanılan görüşme soruları, gözlem ve alanyazın incelemesinden yola çıkılarak hazırlanmıştır. Soruların amaca uygunluğunun testi için üç alan uzmanına danışılmış, anlaşılırlı̆ı̆ının testi için ise ön uygulaması üç ortaokul öğrencisiyle yapılmıştır. Ön uygulamadan alınan dönütlerden ve uzman görüşlerinden yola çıkılarak görüşme sorularına son hali verilmiştir. Görüşme öncesi katılımcılara araştırma hakkında genel bilgi verilmiş ve araştırmaya katılmak isteyen öğrencilerle görüşme yapılacak yer ve zaman belirlenmiştir. Yaklaşık 15-20 dakika süren görüşmeler bire bir, yüz yüze yapıımış ve katılımcıların bilgisi ve onayı kapsamında ses kayıt cihazıyla kaydedilmiştir.

\section{Verilerin Analizi}

Fenomenolojik veri analizinde, araştırma problemiyle ilgili veriler elde edildikten sonra doğrudan veriye gidilmekte ve fenomenin nasıl deneyimlendiğini anlamayı sağlayan önemli açıklamalar, cümleler ve alıntılar yapılmaktadır. Bu önemli ifadelerden hareketle temalar içinde anlam kümeleri/grupları geliştirilir. Daha sonra bu önemli açıklamalar ve temalar, katılımcıların deneyimlerine ilişkin betimleyici bir yazı yazarken kullanılır. Bu tanımlamaların ardından fenomenin "öz" ünü ortaya koyan karma bir betimleme yapılır (Creswell, 2016). "Türk eğitim sisteminde öğrenci olma deneyimi" fenomeni altında Suriyeli ortaokul öğrencilerine, Moustakas'ın belirttiği şu iki temel soru yöneltilmiştir: "Fenomenle ilgili hangi deneyimleri yaşadınız?", "Hangi ortam veya durumlar, fenomenle ilgili yaşadığınız deneyimleri 
etkilemiştir?" (Creswell, 2016). Bu soruların birincisi altında "Derdinizi, isteğinizi çevrenizle rahatlıkla paylaşabiliyor musunuz, bunu yaparken ne gibi sorunlarla karşılaşıyorsunuz?”, "Öğrenim gördüğünüz okulda ne tür sorunlarla karşılaşıyorsunuz?”, “Öğrenim gördüğünüz okulda neler mutlu veya mutsuz hissetmenize sebep oluyor?”, "Okula gelmenizdeki amacınız nedir, ne kadar isteklisiniz?", "Aldığınız eğitimin sizin için faydalı olduğunu düşünüyor musunuz?", "Devlet okullarında Suriyeli çocuklarla mı yoksa Türk çocuklarıyla mı birlikte eğitim almak istersiniz, neden?", "Savaş bitince Suriye'de mi yaşamak istersiniz yoksa Türkiye'de yaşamaya devam mı etmek istersiniz, neden?" ve "Savaş bitince Suriye'ye dönerseniz orada okula devam eder misiniz, neden?" şeklindeki açıcı nitelikte açık uçlu sorular yöneltilmiştir. İkinci soru altında ise Suriyeli ortaokul öğrencilerinin Türk eğitim sistemindeki yaşantılarını etkilediği düşünülen öğretmen, yönetici, arkadaş ve velilerine ilişkin açık uçlu sorular öğrencilere yöneltilmiştir. Bu sorulardan öğretmenlere ilişkin olanlar; "Öğretmenlerinizin size olan yaklaşımı nasıl, sizi sınıfta istiyorlar mı? Neden sizce?", "Öğretmenleriniz sizin anlayacağınız şekilde ders işliyor mu? Nasıl?”, "Öğretmenleriniz sizi derse katmak için çaba harcıyor mu yoksa sizi göz ardı mı ettiğini düşünüyorsunuz? Neden?" şeklindedir. Okul yöneticilerine ilişkin sorular; "Müdür ve müdür yardımcılarının size olan yaklaşımları nasıl, dışlandığınızı hissediyor musunuz?" ve "Okulla ilgili bir sorun yaşadığınızda okul idaresinin tavrı nasıl oluyor?" şeklindedir. Arkadaşlara ilişkin sorular; "Okulda yeteri kadar arkadaşınızın olduğunu düşünüyor musunuz?", "Türk arkadaşlarınız sizi sınıfta istiyorlar mı, size karşı yaklaşımları nasıl?", "Arkadaşlık ilişkileriniz nasıl? Daha çok Türk öğrencilerle mi yoksa Suriyeli öğrencilerle mi arkadaşlık kuruyorsunuz? Neden?", "Dersle veya diğer konularla ilgili durumlarda Türk arkadaşlarınızdan yardım alıyor musunuz? Size nasıl yardım ediyorlar veya neden etmiyorlar?" ve "Okul dışında görüştüğünüz arkadaşlarınız (Türk ya da Suriyeli) var mı? Varsa birbirinizin evlerine gidiyor musunuz, aileler izin veriyor mu? Neden?" şeklindedir. Velilere ilişkin sorular ise; "Aileniz, sizin eğitim almanızı destekliyor mu, sizi okula niçin gönderiyor?", "Ödevleriniz veya derslerinizle ilgili konularda ailenizden destek alıyor musunuz, neden?", "Okulda bir sorun yaşadığınızda veliniz okula gelip ilgileniyor mu ve size karşı tavrı nasıl oluyor?" şeklindedir.

Verilerin analizinde betimsel analiz yöntemi kullanılmıştır. Betimsel analizde amaç, "elde edilen bulguları, düzenlenmiş ve yorumlanmış biçimde okuyucuya sunmaktır" (Yıldırım ve şimşek, 2016). Analiz şu dört aşamada gerçekleştirilmiştir: Öncelikle görüşmelerden elde edilen veriler, araştırmacılar tarafından yazılı hale dönüştürülmüş ve veri analizi için bir çerçeve oluşturulmuştur. Elde edilen tüm veriler birçok kez okunup düzenlenerek tematik çerçeveye göre işlenmiştir. Düzenlenen veriler tanımlanmış ve gerekli görülen yerlerde doğrudan alıntılara yer verilmiştir. Son aşamada ise, tanımlanan bulgular anlamlandırılmış ve bulgular arasındaki neden-sonuç ilişkileri açıklanarak farklı araştırmaların bulgularıyla karşılaştırılmıştır.

\section{Bulgular}

Elde edilen bulgular, dört başlık altında değerlendirilmiştir.

\section{Suriyeli Ortaokul Öğrencilerinin Eğitim Yaşantılarına Yönelik Bulgular}

Yapılan araştırmalarda okullarda Suriyeli öğrencilerin gerek hemcinsleri gerekse karşı cinsle iletişim kuramama, kendilerini ifade edememe, önyargıda bulunma ve hoşgörüden yoksun olma gibi bazı olumsuz iletişim sorunları yaşadıkları tespit edilmiştir (Göktaş, 2016). Bu araştırmada elde edilen bulgular, Türkçeyi yeteri kadar bilmeyenlerin söz konusu olumsuzlukları yaşadıklarını ancak Türkçeyi bilenlerin bu tarz sorunlarının olmadığını ortaya koymaktadır. Dolayısıyla Suriyeli öğrencilerin Türkçeyi iyi seviyede kullanabilmelerinin okullarda olumlu iletişim kurmalarında önemli bir faktör olduğu söylenebilir. Duygu ve düşüncelerini Türk arkadaşlarına aktarma, etkili iletişim kurup kuramamalarına ilişkin sorulara alınan bazı katılımcı görüşlerine aşağıda yer verilmiştir.

"Evet, Suriyeli Türkçeyi bilmeyen arkadaşlar rahatlıkla diyemiyorlar, söyleyemiyorlar. Ben Türkçeyi anladığım için, konuştuğum için iyi anlatıyorum." (Ö7)

"Anlatabiliyorum. Ya genelde en iyi arkadaşıma duygularımı açıklıyorum o yüzden rahatık hissediyorum. Ondan daha önce tanışmıştık iki yıldır alışmıştık birbirimize. Türkçeyi bildiğim için avantaj Türkçeyi bilmeseydim rahatıkla anlatamazdım." (Ö8)

Türkçeyi az bilen Suriyeli öğrenciler kendilerini anlatmakta sıkıntı çektiklerini ve bundan dolayı okullarda Türk öğrencilerle birtakım olumsuzluklar yaşadıklarını ifade etmektedir. Örnek katılımcı görüşlerinden biri şu şekildedir:

"Evet, bazılarını anlatamıyorum. Bazıları zor geliyor... Bazı kelimelerden Türkçe zor geliyor derdimi anlatamıyorum. Çok sıkıntı oluyor. Öteki gün ablama ve özel öğretmenime söylüyorum o Türkşe söylüyor. Okul zor oluyor." (Ö5)

Suriyeli öğrenciler, yeterli dil becerilerini kazanmadan eğitim kurumlarına geldiği için zaman zaman öğretmenler de iletişim kurmakta sorun yaşamaktadır. Derslerde basit Türkçe ifadeleri bile anlayamayan Suriyeli öğrenciler, derse ve 
dersteki etkileşime katılamamaktadır (Bulut, Kanat Soysal ve Gülçiçek, 2018). Benzer şekilde bu araştırmadan elde edilen bulgular da Türkçeyi iyi bilen Suriyeli öğrencilerin dersi anladıklarını, bilmeyenlerin ise dersi anlamakta sıkıntı yaşadıklarını ve derse katııım göstermediklerini ortaya koymaktadır. Türkçeyi iyi bilen katılımcıların görüşlerinden biri şu şekildedir:

"Evet anlıyorum. Eee ben şimdi Türkçeyi biliyorum o yüzden bir de işte ben anlamadıysam soruyorum tabiî ki de onlarda ayrıntılı bir şekilde söylüyorlar falan ve de Araplar yani Suriyeliler olarak dersi hiç dinlemiyorlar belki dinleseler başarılı olabilirler. Dinleseler zaten Türkçeyi öğrenirler kurslarının da yardımı sayesinde başarılı da olabilirler." (Ö8)

Türkçeyi az bilen katılımcıların görüşleri ise şu şekildedir:

"Hayır. Öğretmenim yani neyi söylüyor ben anlamıyor ve Türkçe ben çok bilmiyorum yani. Bir kelime hocam söylüyorum ben onu anlamiyorum." (Ö2)

"Bazılarını anlamıyorum bazen anlıyorum. Bazılarını hoca iyi anlatmadığı için mi ben mi anlamadığım için mi derse katılmadığım için bilmiyorum. Ben Türkçeyi çok iyi bilmiyorum Türkler kadar bilseydim daha başarılı olurdum." (Ö7)

Elde edilen bulgular tüm katılımcıların öğrenim görme konusunda oldukça güdülenmiş olduklarını ve bir üniversitede okumaya karşı istekli olduklarını ortaya koymaktadır. Okula isteyerek ve mutlu olarak geldiklerini belirten Suriyeli öğrencilerin, derse katılma konusunda da istekli oldukları gözlenmiştir. Bu bulguya ilişkin bazı görüşlere aşağıda yer verilmiştir.

"Çok istiyorum. Hocam çünkü yani hoca bana çalışkan söylemek için yani böyle sınavda iyi almak için sınıfta ben iyi olsun yani. Bir kişi bana tembel demesin yani. Ayrıca üniversiteye girmek istiyorum, katılmak istiyorum." (Ö1)

"Kendi isteğimle okula geliyorum. Bence öğrenciler beni çok severler. Öğretmenler de beni çok severler. Ben de başarılı olmak istiyorum." (Ö4)

"Kendi isteğimle. Ben çok hayaller var yani göz doktoru olmak için okula gitmek istiyorum yani böyle." (Ö6)

Dil, kültür ve yaşam tarzlarının farklı oluşu nedeniyle Türk toplumuna uyum sağlamakta zorluk yaşasalarda Suriyeli öğrencilerin, kendileri gibi Suriyeli olanlarla değil de Türk öğrencilerle birlikte eğitim görmek istedikleri tespit edilmiştir. Türk öğrencilerle etkileşim içinde olmanın Türkçeyi daha iyi ve hızlı öğrenmeye katkı sağlayacağını belirten Suriyeli öğrencilerin, Türk öğrencileri kendilerine rol model aldıkları görülmektedir. Bu bulguya ilişkin bazı görüşler aşağıda yer verilmiştir.

"Türk. Burada sistem daha iyi. Yani Türk olunca çok mutlu olurum. Türk olursa ben derslere çok çalışacağım. Bir de Suriyeliler arkadaşım değişmezler. Türk öğrencilerle Türkçeyi daha iyi öğrenirim yani." (Ö1)

"Türk. Çünkü artık Türkiye'deyim yani. Türkçeyi öğrenmeyecektim. Çünkü onlarla iletişim kuruyorum onlarla. Türkçeyi daha çok öğreniyorum." (Ö3)

"Türklerle birlikte. Çünkü öğretmenler yani Türk öğrencilerden etkilenir. Eğer mesela Suriyelilerle hayatta Türkçe öğrenemezdim. Sadece öğretmenle öğrenemem. Bir de arkadaşlarım olması lazım." (Ö4)

Suriyeli öğrenciler ülkelerine duydukları sevgi ve bağlılığa rağmen bulundukları ortamdan memnun olmanın verdiği haklılıkla geleceklerini Türkiye'de görmekte ve vatanlarına dönme konusunda istekli görünmemektedir. Bu bulguya ilişkin katılımcı görüşlerinden bazıları şu şekildedir:

"Türkiye'de. Türkiye daha iyi babam işi burada oldu bizde ev aldık burada." (Ö5)

"Türkiye'de. Çünkü Suriye'de savaşlar var ya liseler yok. Çünkü arkadaşlarım var." (Ö6)

"Türkiye'de çünkü ben hayatımın yarısını Türkiye'de geçirdim orada dört yıl geçirdim sadece. Burada beş yıl altı yıl oldu." (Ö7)

Suriye'de savaş olmamış olsaydı orada da okula gitmiş olacaklarını belirten öğrencilerin tamamı savaş bitince Suriye'ye döndüklerinde Suriye'de okula gitmek istediklerini ancak bu durumun onlar için çok zor olacağını ifade etmektedir. Bazı örnek ifadelere aşağıda yer verilmiştir.

"Evet, ama çok zor olacak. Çünkü artık yani sadece Türkçe yazıyorum. Sadece Türkçe konuşuyorum. Daha çok Türkçe konuşuyorum zor olacak. Arapça çok zor." (Ö3)

"Evet, Büyünce bir şey olayım diye mühendis avukat falan." (Ö5)

"Giderdim. Ama çok zor olacak çünkü Arapçayı unutmak üzereyim." (Ö8)

\section{Suriyeli Ortaokul Öğrencilerinin Öğretmen ve Okul İdaresiyle Olan Yaşantılara Yönelik Bulgular}

Eğitim öğretim sürecinde öğretmenlerin öğrencileriyle olan iletişimleri kuşkusuz kazanımların davranışa dönüşmesi açısından oldukça önemlidir. Olumlu iletişim öğrenci başarısında pozitif bir etkiye sahipken olumsuz iletişim tam dersi bir etki oluşturmaktadır. Bu nedenle öğretmenin sınıf ortamında öğrencilerle iletişimi korkuya dayalı değil eşitlik temelinde saygıya ve sevgiye dayanmalıdır. Ayrıca öğrenciler, öğretmenleri tarafından dışlanmadıklarından da emin olmalıdır. Çeliköz ve Türkan’ın (2017) da belirttikleri gibi bir grup üyesinin ait olduğu grubun dışında tutulması, mevcut bir gruba bireyin kabul edilmemesi veya oluşmakta olan bir gruba dâhil edilmemesi olarak nitelendirilen dışlanma, birçok alanda ya da çevrede karşılaşılan bir durum olmakla birlikte eğitim kurumlarında yaşanması birçok problemi de beraberinde getirmektedir. Dolayısıyla Suriyeli öğrencilerin sınıflarda kendilerini güvende hissetmelerinde ve başarıya ulaşmalarında öğretmenleriyle olan iletişimleri oldukça önemlidir. 
Araştırma kapsamında Suriyeli öğrencilere, sınıf ortamında öğretmenleri tarafından dışlanıp dışlanmadıklarına ilişkin sorular yöneltilmiştir. Ö2 dışındaki tüm öğrenciler öğretmenlerinin kendilerine iyi davrandıklarını, diğer bir ifadeyle kendilerini dışlamadıklarını belirtmektedir. Bu bulguya ilişkin bazı görüşlere aşağıda yer verilmiştir.

"Çok iyi davranıyorlar. Çünkü insanız sonuçta." (Ö4)

"Dışlanma öyle bir şey yok tabiî ki çünkü ben başarılıyım zaten yazılılardan yüz falan alıyorum yani arkaya atmıyorlar ben de katılıyorum derse." (Ö8)

Ö2 ise öğretmenleri tarafından pek de istenmediğini belirtmiştir. Suriyeli olmasının değil de dersleri anlamamasının buna sebep olduğunu şu şekilde dile getirmektedir:

"Yani kötü. Eee ben hiçbir şey anlamıyorum. Anlamadığım için Suriyeli olduğum için değil."

Öğretmenlerin Suriyeli öğrencileri dışlamadıklarında dair diğer bir gösterge ise Türk öğrencilere davrandıkları gibi Suriyeli öğrencilere davrandıklarını gösteren bulgudur. Bu konuda dile getirilen görüşlere aşağıda verilmiştir.

"Herkese eşit davranıyorlar. Çok iyi yani fark etmez. Bir öğrenci misal kötü bir şey söylerse hoca buna yani konuşuyor, bağırıyor. Yani böyle yapma siz arkadaş çocuklar." (Ö1)

"Eşit davranıyorlar. Türkçe bilseydim ama başarılı olmasaydım bence eşit davranacaklardı. Ama çok sevmeyecekler beni yani. Ben Türkçe biliyorum neden başarılı olmuyorum diye." (Ö3)

"Evet, aynı. Mesela ödev aynı ödevi veriyor. Ben yukarıdaysam ödev verdiği hoca bir şey koymuyor eksi falan." (Ö5)

Sınıf ortamında başarıyı etkileyen birçok etkenin yanına öğretmenin, öğrencilerin seviyelerine göre dersi işleyip işlememesi de eklenebilir. Öğretmen, empati kurarak gerektiğinde her öğrencinin seviyesine inebilmeli, öğrettiklerinin herkes tarafından iyice anlaşıldığından emin olmalıdır. Özellikle Suriyeli öğrencilerin bulunduğu sınıflarda öğretmen ders işlerken bu öğrencileri göz önünde bulundurarak dersin işleyişini düzenlemelidir. Öğretmen, öğrencilere çekinmeden, azarlanma kaygısı taşımadan istediği soruları sorabilme rahatlığını verebilmelidir. Bu konuya ilişkin yöneltilen soruya katılımcıların önemli bir çoğunluğu, öğretmenlerin Suriyeli öğrencileri de dikkate alarak dersleri işlediklerini belirtmektedir. Bu bulguya ilişkin bazı görüşlere aşağıda yer verilmiştir.

"Işsliyor. Dersleri anlıyorum ben yani. Hoca bir soru veriyor, ben yanlış çözerse hocaya gidiyorum, hoca ben bunu anlamadı, hoca bana söylüyor yani, anlatıyor bana. Bunlar (başarısız olan Suriyeli öğrenciler) yani Türkçede zayıflar... Biraz çalışsınlar iyi olurlar. Anlarlar... Şimdi kursa gidiyorlar. Hiç çalışmıyorlar. Biraz çalışsalar çok iyi olurlar." (Ö1)

"Evet, fen hoca ben soruyu götürüyorum o bana anlatıyor." (Ö6)

"Evet ediyorlar. Doğru anlatıyor herkes anlıyor." (Ö7)

Ö2, Türkçeyi iyi bilmediğinden dersleri anlayamadığını, öğretmenlerin dersleri onun anlayabileceği gibi anlatmasını beklediğini belirtmektedir. Ö5 ise öğretmenlerin bazen kendisini dikkate alarak dersleri işlediğini, bu nedenle özel öğretmene başvurduğunu şu şekilde belirtmektedir:

"Bazen. Ama özel öğretmenim var her gün gidiyorum o geri anlatıyor, dersler veriyor." (Ö5)

Öğrencilerin derse katılımının, akademik başarıları üzerinde olumlu bir etkiye sahip olduğu bilinmektedir (Çelik, Örenoğlu Toraman ve Çelik, 2018). Dolayısıyla öğretmenlerin, Suriyeli öğrencilerin de derslere katılımlarını sağlamada göstermiş oldukları çaba önemlidir. Bu araştırmanın bulguları, öğretmenlerin Suriyeli öğrencileri derse katma konusunda çaba sarf ettiklerini göstermektedir. Bu bulguya ilişkin bazı görüşler şu şekildedir:

"istiyor. Hepimize de istiyor. Bütün öğretmenler istiyor." (Ö1)

"Evet, hoca bana diyor, kaldırıyor, soru veriyor ben cevaplıyorum. Anlamadıysa hoca bana anlatıyor." (Ö6)

"Herkese aynı davranıyorlar. Bazen beni bazen Türkleri (tahtaya) çıkartıyor." (Ö7)

Araştırmadan elde edilen bulgulara göre Suriyeli öğrencilerin Türkiye'de eğitim gördükleri okullarda okul idaresi tarafından da herhangi bir ayrımcılığa tabi tutulmadıkları, dışlanmadıkları tespit edilmiştir. Konuya ilişkin bazı görüşlere aşağıda yer verilmiştir.

"Çok iyi davranıyorlar. Herkes aynı fark etmez." (Ö1)

"Sorun çözmek için yardım ederler." (Ö6)

Ö7 bu olumlu iletişimde kendilerinin Türkçe bilmelerinin etkisinin olduğunu şu şekilde ifade etmektedir:

"Eşit dinlerler. Ama bir kez Suriyeli arkadaşım bir kişi Türk idareye gittiler beraber X müdür yardımcısı daha çok Türkü dinliyordu. Suriyeli çok konuşmadı Türkçe bilmediği için."

\section{Suriyeli Ortaokul Öğrencilerinin Türk Öğrencilerle Olan Yaşantılara Yönelik Bulgular}

Suriyeli öğrencilerin MEB'e bağlı devlet okullarında yaşadıkları sorunların başında Türk öğrencilerin kendilerine yönelik olumsuz tutumları bulunmaktadır. Bu araştırmada elde edilen bu bulguyla örtüşen birkaç araştırmaya ulaşılmıştır. Sözgelimi, Çoşkun ve Emin'in (2016) araştırmalarında devlet okullarında öğrenim gören Suriyeli öğrencilerin uyum sorunu yaşamalarında okul idaresi, öğretmen ve velilerin yanı sıra diğer öğrencilerin kendilerine yönelik dışlama, ötekileştirme, akran zorbalığı gibi olumsuz tavır ve 
davranışlarının etkili olduğu belirtilmektedir. İstanbul Bilgi Üniversitesi (2015) tarafından yapılan çalışmada ise Suriyeli öğrenciler, Türk öğrencilerin kendileriyle oyun oynamadığını, sözlerine inanmadığını, arkadaşlık etmediğini belirtmektedir. Özer, Komsuoğlu ve Ateşok'un (2016) çalışmalarında da yaşı ilerleyen ve okula başlama yaşı geciken Suriyeli öğrencilerin Türkçeyi öğrenmelerinin zorlaştığı ve bu durumun dışlanma gibi sınıf ve okul içinde çeşitli sorunlara yol açtığı belirtilmektedir.

Türk öğrencilerin Suriyeli öğrencilere yönelik sergiledikleri olumsuz tutum ve davranışlar bu araştırmanın dikkat çeken sonuçlarından birini oluşturmaktadır. Bu bağlamda Suriyeli öğrencilerin büyük çoğunluğu, Türk akranlarından beklenen ilgi ve kabullenmeyi görmediklerini şu şekilde dile getirmişlerdir:

"Bazen. Mesela beden dersinde futbol oynarken bazen oynatmıyorlar. Galiba Suriyeli olduğum için. Bir kaçı böyle üç kişi, dört kişi. Ama bu arkadaşlar derste başka oyunda başka ödevlerde yardımcı olurlar galiba bazen veriyorlar bazen vermiyorlar." (Ö7) (Ö8)

"Yani ben aslında onlarla ilgilenmeyi fazla istemiyorum belki kalplerini kırabilirim diye o nedenle onlardan uzak duruyorum."

Bu olumsuz örneklerin yanı sıra Suriyeli öğrencilerin Türk akranlarından beklenen ilgi ve kabullenmeyi gördüklerine dair örneklere de rastlanmaktadır. Sözgelimi:

"Arkadaşlarım bana dersi anlatıyor teneffüste. Arkadaşım X var ben soruyu anlamadım o bana anlatırdı." (Ö6)

"Oluyorlar. Mesela ben bir kez ödev yapmamıştım, anlamamıştım ve arkadaşa gittim sınıfımda ödev neydi diye sordum verdi ödevi." (Ö7)

Türk öğrencilerin Suriyeli öğrencileri kabullenmelerinin altında, Suriyeli öğrencilerin Türkçeyi yeterli düzeyde bilmelerinin yanı sıra başarılı olmalarının da etkili olduğu algısı bulunmaktadır. Bu bulguya yönelik görüşlerden biri şu şekildedir:

“Evet, sınıfımızı kurtaracaksınız diyor. Çünkü başarılı bir öğrenci tabiî ki her sınıfta istenir" (Ö4)

Araştırmadan elde edilen bulgulara göre daha çok kendi aralarında zaman geçiren Suriyeli öğrencilerin, Suriyeli akranlarından ziyade Türk akranlarıyla birlikte vakit geçirmek istedikleri görülmüştür. Bu tespite yönelik örnek görüşler aşağıda verilmiştir:

"Türk. Türk okullardayız. Türklerle arkadaş kurmamız gerekiyor. Çünkü Suriyeliler derslerle ilgilenmiyorlar. Saygısızca davranıyorlar." (Ö3)

"Türk. Daha çok Türk olmasını isterim. Türkler dahi iyi. Suriyeliler bazı pis konuşuyor." (Ö5)

"Türk arkadaş isterim daha böyle Türkçe konuşa bilirim diye, sosyalleşeyim diye. Suriyeliler Türkçe konuşmadıkları için ben daha çok Türkçe konuşmayı isterim." (Ö7)

Suriyeli öğrenciler okul dışında daha çok Türk öğrencilerle birlikte zaman geçirmek istediklerini belirtseler de Türk öğrencilerden çok genellikle birbirleriyle görüştükleri ve ev ziyaretinde bulundukları tespit edilmiştir. Bu bulguyla ilgili bazı görüşler şu şekildedir:

"Okul dışında görüştüğüm Türk arkadaşım var. Evlerine gitme yani öyle bir şey olabilir ama olmadı. Ailem izin verir. Anne baba bana çok söylüyor dost olun" (Ö1)

“Arap arkadaşım var. Iki tane de Türk var. Birbirimizin evine gitmiyoruz. Parkta görüşüyoruz ödevlerim var. Zaman yok." (Ö6)

"Suriyeli çok var Türk de var birkaç tane. Türkün evine gitmedik ama Suriyelilerin gidiyoruz. Çünkü davet etmiyorlar. Suriyeliler davet ediyor. Türkler davet etse giderim. Ben de davet etsem gelirler." (Ö7)

Bu olumsuz örneklerin yanı sıra Suriyeli öğrencilerin okul dışında Türk öğrencilerle birlikte zaman geçirdiklerine dair örnekler de bulunmaktadır. Sözgelimi:

"Var. Gidip geliyoruz. Bazen eğlenmek bazen ders çalışmak için." (Ö4)

"Sadece Türk var. Birbirimizin evine gidiyoruz. Ben onlarla Türkçe konuşa biliyorum ve onlar bana değer veriyor. Onlar bana değer veriyorlarsa ben de onlara değer veririm. Türkçe bilmeseydim rahat iletişim kuramazdım ancak giderdim diye düşünüyorum." (Ö8)

Suriyeli öğrenciler, Türk öğrenciler tarafından dışlanmamalarını daha çok Türkçe bilmelerine ve başarılı olmalarına bağlamaktadır.

\section{Suriyeli Ortaokul Öğrencilerinin Aileleriyle Olan Yaşantılara Yönelik Bulgular}

Öğrencilerin akademik başarısını etkileyen okul içi ve okul dışı birçok etkenden söz etmek mümkündür. Okul dışı etkenler söz konusu olduğunda aile, öğrencinin akademik başarısı üzerinde önemli bir etkiye sahiptir. Aileler hem çocuklarıyla kuracakları iletişimin niteliği hem de okul ile gerçekleştirecekleri iş birliğiyle çocuklarının akademik başarısına önemli katkı sağlayabilir (Aslanargun, 2007). Özellikle anne ve babalar çocuğunu ne kadar iyi dinler, tanır ve çocuğunun ilgilerini, meraklarını anlayıp onu desteklerse çocuğunu okula isteyerek gitmesi ve derslerini severek çalışması konusunda motive edebilir. Bu araştırmadan elde edilen bulgular velilerin, çocuklarının okula gitmeleri konusunda istekli olduklarını ve eğitim görmelerini desteklediklerini ortaya koymaktadır. Bu bulguya ilişkin bazı görüşler aşağıda verilmiştir: 
"Ailem okumamı istiyor çok. Misal yani doktor olmak için, yani kibar olmak için." (Ö1)

"Evet, müstakbelde doktor olmam için gelecekte." (Ö3)

“istiyor. Çünkü öğreneceğim daha çok öğreneceğim. Göz doktoru olacağım ve fen lisesine girmek istiyorum." (Ö6)

Araştırmada ulaşılan bulgular Türkçe bilen ailelerin, çocuklarının derslerinde, ödevlerinde kendilerine yardımcı olduklarını; yeterince bilmeyenlerin ise bu konuda çocuklarına katkı sağlayamadığını ortaya koymaktadır. Konuya ilişkin örnek öğrenci ifadelerinden bazıları şu şekildedir:

"Annem biliyorum. Babam bilmiyor. Bilseler daha çok yardımcı olurlar." (Ö2)

"Evet, Ablam mesela sınav var, bak hangisi çok zor onu tekrar eder ve özel hocam geri dersleri anlatır." (Ö5)

"Evet, Bazen ödevlerimi yapamıyorum ablamın yanına gidiyorum onlar beni yardımcı oluyor. Türkçeyi iyi bilselerdi daha çok yardımcı olurlardı." (Ö7)

Çocuğun okulda geçirdiği zaman, ailesi ve çevresiyle geçirdiği zamana göre daha kısa olduğu için öğretmenlerin aile tarafından desteklenmesi, çocuğun okul başarısını ve kişisel gelişimini desteklemektedir (Çınkır ve Nayır, 2017). Aile bireylerinin okul etkinliklerine katılımı ve okulda çocukların yaşadıkları sorunlarla yakından ilgilenmeleri öğrenci başarısını artırmakta ve öğrencinin kedisini güvende hissetmesini sağlamaktadır. Bu araştırmada Suriyeli öğrencilerin okulda herhangi bir sorun yaşamaları durumunda velilerinin okula geldiği görülmektedir. Bu bulguya yönelik bazı görüşler şu şekildedir:

"Gelir. Ama olmadı sorun, sıkıntı yani. Annemin arkadaşı var yardımcı oluyor. Velilerim kursa gidiyor Türkçe öğreniyor." (Ö1)

"Geliyor. Tabiî ki gelecek. Önce olayı anlatıyorum. Anlıyorlar kim haklı kim haksız anlıyorlar ondan sonra konuşuyorlar. Ama bağırmıyorlar tabiî ki. Eğer çok büyük bir sorunsa okula gelirler ama eğer basit bir bence gelmezler." (Ö4)

"Evet, o okulda çok sorunum oldu. Geldi baba. O sefer Cuma günüydü ben de sınıftaydım hoca gelmedi. Geldim Türkler sen Suriyelisin vurdular ben de dövüştüm ondan sonra oturdum geri hepsi sınıf bana vurdu. Babam geldi şikâyet etti. Müdür oğlanları getirdi. Bir de babaları geldiler. Bilmiyorum ne müdür yazdı babalarına. Müdür ben haklıyım dedi." (Ö5)

\section{Sonuç ve Öneriler}

Suriyeli öğrencilerin okullara devam etme hakkına ilişkin eğitim sistemi içinde öğretmen, idareci ve diğer personellerin tutumlarında çeşitlilik olduğu görülmektedir. Paydaşların bir bölümü bu durumu, eğitim hakkı bağlamında değerlendirirken, önemli bir bölümü ise Türkiye'nin Suriyelilere sunduğu bir 'lütuf' şeklinde değerlendirmektedir (İstanbul Bilgi Üniversitesi, 2015). Buna rağmen bu araştırmanın sonuçlarından birini oluşturan özellikle başarılı öğrenciler olmak üzere Suriyeli öğrencilere söz konusu olumsuz tutumun yansıtılmamış olması önemli bir sonuçtur. Başta derslerinde başarılı olanlar olmak üzere Suriyeli öğrenciler, Türkiye'de eğitim gördükleri okullarda öğretmenleri tarafından dışlanmadıklarını, ayrımcılığa tabi tutulmadıklarını, kendilerine iyi davranıldığını, Türk öğrencilere davranıldığı gibi davranıldığını ve öğretmenlerin dersleri işlerken kendilerini göz ardı etmediklerini ve derse katılmaları konusunda çaba harcadıklarını belirtmektedir. Katılımcıların nezdinde bu yaklaşımın temel sebepleri başarılı olmaları ve Türkçeyi iyi düzeyde bilmeleridir. Bu algı, öğretmenlerin öğrencileri kimliklerine göre değil, başarılı olup olmamalarına göre değerlendirdiklerini ortaya koymaktadır. Bu bulgu, Türk öğrencilerin bakışından da öğretmenlerinin başarılı ve başarısız öğrencilere yönelik tutumlarının incelenmesi gerekliliğini ortaya koyduğu gibi böyle bir çalışmanın yapılması bu araştırmanın sonucunu da anlamlı kılacaktır.

Araştırmada Suriyeli öğrencilerin önemli bir çoğunluğunun Türk akranlarından beklenen ilgi ve kabullenmeyi görmedikleri tespit edilmiştir. Katılımcı görüşlerine göre Türk öğrencilerin Suriyeli öğrencileri kabullenmelerinde, Türkçeyi etkin kullanma ve derslerde başarılı olmaları belirleyici olmaktadır. Öte yandan daha çok kendi aralarında zaman geçiren Suriyeli öğrencilerin, Suriyeli çocuklardan ziyade Türk çocuklarla birlikte vakit geçirmek istedikleri görülmektedir. Bu isteği besleyen etmenlerin başında Türkçeyi öğrenmenin kolaylaşması yer alırken Suriyeli bazı öğrencilerin kendi aralarında olumsuz davranış sergilemelerinden ve derslere karşı ilgisiz olmalarından kaynaklanan rahatsızlık da bulunmaktadır. Benzer şekilde okul dışı ortamlarda daha çok Türk öğrencilerle birlikte vakit geçirmek isteyen Suriyeli öğrenciler, Türk öğrencilerden gerekli karşılığı alamadıklarından daha çok birbirleriyle etkileşim içinde olmaktadır. Toplumda kültürel kaynaşma sağlanması adına bu yaklaşımın istenmediği açıktır. Suriyeli öğrencilerin Türkçeyi istendik biçimde kullanabilmeleri ve Türk kültürünü benimseyebilmeleri için eğitim kurumlarımızda Suriyeli öğrenciler ile Türk öğrenciler arasında iş birliğine ve gruplara dayalı etkinliklere ağılık verilmelidir. Okul dışı çeşitli öğrenme ortamları oluşturularak öğrencilerin kaynaşmalarına yönelik faaliyetlerde bulunulmalıdır. Bunun için de mutlaka Suriyeli öğrencilerle Türk öğrencilerin birlikte eğitimlerinin devamlılığı sağlanmalıdır. Dolayısıyla Emin'in (2016) de belirttiği gibi akranlarından gerekli ilgiyi görmeleri için diğer bir ifadeyle ön yargı, hoşgörüsüzlük ve çatışmaların önlenmesi için başta Suriyeli öğrencilerin olduğu okullar olmak üzere tüm eğitim kurumlarında ve toplumda farkındalık eğitimleri verilmesi oldukça önemlidir. Araştırmalarda erken yaşlarda okula başlayan Suriyeli çocukların Türkçeyi daha kolay öğrendikleri, iletişim engelini daha kolay aştıkları gözlemlenmiş ve bu durumun da uyum sağlamalarını ve kendilerini iyi hissetmelerini sağladığı görülmektedir (İstanbul Bilgi Üniversitesi, 2015). Bireylerin geçmişini ve kültürel mirasını öğrenmesinde, içinde bulunduğu toplumdaki diğer bireylerle iletişim kurmasında, geleceğine dönük hayallerini ve düşüncelerini açıklamasında ve kendisini ifade etmesinde çok önemli bir araç olan dil, bir milleti ayakta tutan, onun varlığını ve devamlılığını sağlayan ve bireyleri birbirine yaklaştırarak birlik duygusunu yaratan unsurdur. Dolayısıyla Suriyeli öğrencilerin Türkçe konuşan akranlarıyla olumlu iletişim kurmalarında Türkçeyi öğrenmeleri oldukça önemlidir. 
Bu nedenle Suriyeli öğrencilerin Türkçe eğitimine azami önem verilmelidir. Sadece ders kitaplarına bağlı, klasik öğretim uygulamalarıyla Suriyeli öğrencilere Türkçe öğretiminin yeterli olamayacağından (Gün, Akkaya ve Kara, 2014) oyun temelli öğretimin yanı sıra teknolojik araçlar ve materyallerle, dil kartlarıyla, güncel örneklerle, sanatsal ve sportif faaliyetlerle, okul dışı öğrenme etkinlikleriyle öğrencilerin dil öğrenmeleri desteklenmelidir.

Araştırmada ulaşılan bir diğer sonuç, Suriyeli öğrencilerin velileri, çocuklarının öğrenim görmelerini destekledikleri ve çocuklarının sorunlarıyla ilgilendikleri yönündedir. Suriyeli öğrencilerin Türk eğitim sistemine entegrasyonuna yönelik yapılan akademik çalışmalarda öğrencilerin ve ailelerinin görüşlerine de yer verilen çeşitli araştırmalar yapılmalıdır.

Araştırma sonucunda Suriyeli öğrencilerin öğrenim görme konusunda oldukça güdülenmiş oldukları ve bir üniversitede okumaya karşı istekli oldukları tespit edilmiştir. Ayrıca Suriyeli öğrencilerin vatanlarına dönme konusunda isteksiz oldukları saptanmıştır. Geleceklerinde Türkiye'yi gören Suriyeli öğrencilerin akıbetlerine yönelik kararlar ivedilikle verilmeli ve ona göre eğitimleri düzenlenmelidir. Zira Türkiye'ye özgü eğitim programlarıyla öğrenim gören Suriyeli öğrencilerin ülkelerine dönmeleri halinde gördükleri bu programın işlevselliği ve geçerliliği olmayacaktır. Aksine onlar için emek ve zaman kaybı olacağı gibi Türk eğitim sisteminde yarattı̆̆ birçok sorun ve sıkıntının yanı sıra Türkiye için de hem zaman hem de ekonomik kayıp olmanın ötesine gitmeyecektir. Öte yandan Türk eğitim sistemine dâhil edilen Suriyeli öğrencilere Arapça ve ülkelerinin tarih ve coğrafyasına ilişkin derslerin verilmediği görülmektedir. Hâlbuki hâlihazırda Suriyeli öğrencilerin kendi ülkelerine dönmeyeceklerine yönelik bir karar bulunmamaktadır. Dolayısıyla kendi ülkelerinin tarihine, coğrafyasına, diline daha genel anlamda kültürüne yabancı olarak yetişen bu öğrencilerin, ülkelerine dönmeleri halinde yaşayacakları kültürel çatışma göz ardı edilmemelidir. Bu bağlamda düşünüldüğünde Suriyeli öğrencilere yönelik ya eğitim kurumlarımızda Arap dil ve Suriye kültürüne ilişkin seçmeli derslere yer verilmeli ya da takviye kurslarla bu eksiklik giderilmeye çalışılmalıdır. Konuyla ilgili olarak Levent ve Çayak'ın (2017) da belirttikleri gibi okul yöneticilerine ve öğretmenlere Suriyeli öğrencilerin sahip olduğu kültür ile Türk öğrencilerin sahip olduğu kültür çerçevesinde eğitim hizmetini en iyi şekilde sunabilmeleri için çok kültürlü eğitim seminerleri verilmesi gerekmektedir. Dahası Türkiye'ye gelen Suriyelilerin uzun yıllar Türkiye'de kalacakları göz önüne alındığında eğitim fakültelerinde öğretmen adaylarının da meslek yaşamları süresince çok kültürlü eğitime yönelik yeterliklerini geliştirmek için çok kültürlü eğitime yönelik derslere yer verilmelidir.

\section{Kaynakça}

Aktekin, S. (Ed.). (2017). Sınıfında yabancı uyruklu öğrenci bulunan öğretmenler için el kitabı. Ankara: Millî Eğitim Bakanlığı Öğretmen Yetiştirme ve Geliştirme Genel Müdürlüğü.

Alpaydın, Y. (2017). An Analysis of educational policies for school-aged Syrian refugees in Turkey, Journal of Education and Training Studies, 5(9), 36-44.

Aras, B., Yasun, S. (2016). The educatıonal opportunitıes and challenges of Syrian refugee students in Turkey: temporary educatıon centers and beyond. İstanbul: İstanbul Policy Center -Sabancı University- Stiftung Mercator Initiative. Erişim adresi: http://ipc.sabanciuniv.edu/wp-content/uploads/2016/07/Bulent-Aras-and-Salih-Yasun-1.pdf

Aslanargun, E. (2007). Okul - aile işbirliği ve öğrenci başarısı üzerine bir tarama çalışma. MANAS Journal of Social Studies, 8, 119135.

Baltaci, A (2017). A comparison of Syrian migrant students in Turkey and Germany: entrepreneurial tendencies and career expectations. European Journal of Educational Research, 6(1), 15-27.

Bulut, S., Kanat Soysal, Ö., Gülçiçek, D. (2018). Suriyeli öğrencilerin Türkçe öğretmeni olmak: Suriyeli öğrencilerin eğitiminde karşılaşılan sorunlar. Uluslararası Türkçe Edebiyat Kültür Eğitim Dergisi, 7(2), 1210-1238.

Büyükikiz, K. K., Çangal, Ö. (2016). Suriyeli misafir öğrencilere Türkçe öğretimi projesi üzerine bir değerlendirme. Uluslararası Türkçe Edebiyat Kültür Eğitim Dergisi, 5(3), 1414-1430.

Creswell, J. W. (2016). Nitel araştırma yöntemleri beş yaklaşıma göre nitel araştırma ve araştırma deseni. (Çev. Mesut Bütün ve Selçuk Beşir Demir). Ankara: Siyasal Kitabevi.

Creswell, J. W. (2017). Araştırma deseni nitel, nicel ve karma yöntem yaklaşımları. (Çev. Selçuk Beşir Demir). Ankara: Eğiten Kitap Yayıncılık.

Çelik, S., Örenoğlu Toraman, S., Çelik, K. (2018). Öğrenci başarısının derse katılım ve öğretmen yakınlığıyla ilişkisi. Kastamonu Üniversitesi Kastamonu Eğitim Dergisi, 26(1), 209-217.

Çeliköz, N., Türkan, A. (2017). Ortaöğretim 9. sınıf öğrencilerinin okulda dışlanmışlık düzeylerinin incelenmesi. Ondokuz Mayıs Üniversitesi Eğitim Fakültesi Dergisi, 36(2), 45-58.

Çınar, i. (2008). illköğretimin önemi ve öğretmen, Eğitişim Dergisi. Erişim adresi: http://www.egitisim.gen.tr/tr/index.php/arsiv/sayi-11-20/sayi-20-demokrasi-egitimi-ekim-2008/279-ilkogretimin-onemive-ogretmen

Çınkır, Ş., Nayır, F. (2017). Okul aile işbirliği standartlarına ilişkin veli görüşlerinin incelenmesi. Hacettepe Üniversitesi Eğitim Fakültesi Dergisi, 32(1). 245-264. 
Çoşkun, i., Emin, M. N. (2016). Türkiye'deki Suriyelilerin eğitimde yol haritası, fırsatlar ve zorluklar. İstanbul: Siyaset, Ekonomi ve Toplum Araştırmaları Vakfı (SETA). Erişim adresi: http://file.setav.org/Files/Pdf/20160906135243_turkiyedeki-suriyelilerinegitiminde-yol-haritasi-pdf.pdf

Emin, N. M. (2016). Türkiye'deki Suriyeli çocukların eğitimi: temel eğitim politikaları. İstanbul: Siyaset, Ekonomi ve Toplum Araştırmaları Vakfı (SETA). Erişim adresi: http://file.setav.org/Files/Pdf/20160309195808_turkiyedeki-suriyeli-cocuklarinegitimi-pdf.pdf

Ertaş, H., Çiftçi Kıraç, F. (2017). Türkiye'de Suriyeli göçmenlere yönelik yapılan eğitim çalışmaları. Selçuk Üniversitesi Sosyal ve Teknik Araştırmalar Dergisi, 13, 99-110.

Ertürk, S. (1975). Eğitimde program geliştirme. Ankara: Meteksan.

Göktaş, P. (2016). Z kuşağındaki mülteci öğrencilerin kültürel iletişim farklılıklarının değerlendirilmesi üzerine bir araştırma: Gürkan İmam Hatip Ortaokulu örneği. Türk Dünyası Eğitim Araştırmaları Dergisi, 1(1), 32-38.

Gün, M., Akkaya, A., Kara, Ö. T. (2014). Yabancılara Türkçe öğretimi ders kitaplarının Türkçe öğretim merkezlerinde görev yapan öğretim elemanları açısından değerlendirilmesi. Turkish Studies International Periodical For The Languages, Literature and History of Turkish or Turkic, 9(6), 1-16.

İçişleri Bakanlığı (2018). Göç İdaresi Genel Müdürlüğü. Erişim adresi (27 Aralık 2018): http://www.goc.gov.tr/icerik6/gecicikoruma_363_378_4713_icerik

İstanbul Bilgi Üniversitesi (2015). Suriyeli Mülteci çocukların Türkiye devlet okullarındaki durumu politik ve uygulama önerileri, İstanbul Bilgi Üniversitesi Çocuk Çalışmaları Birimi. Erişim adresi: http://cocuk.bilgi.edu.tr/wpcontent/uploads/2015/09/Suriyeli-Cocuklar-Egitim-Sistemi-Politika-Notu.pdf

Levent, F., Çayak, S. (2017). Türkiye'deki Suriyeli öğrencilerin eğitimine yönelik okul yöneticilerinin görüşleri. Hasan Ali Yücel Eğitim Fakültesi Dergisi, 14-1(27), 21-46.

Mercan Uzun, E., Bütün, E. (2016). Okul öncesi eğitim kurumlarındaki Suriyeli sığınmacı çocukların karşılaştıkları sorunlar hakkında öğretmen görüşleri. Uluslararası Erken Çocukluk Eğitimi Çalışmaları Dergisi, 1(1), 72-83.

Merriam, S. B. (2013). Nitel araştırma desen ve uygulama için bir rehber. (Çev. Selahattin Turan). Ankara: Nobel Akademik Yayıncilık.

Milli Eğitim Bakanlığı (MEB). (2018). Hayat Boyu Öğrenme Genel Müdürlüğü: Göç ve Acil Durum Eğitim Daire Başkanlığı. Erişim adresi: https://hbogm.meb.gov.tr/meb_iys_dosyalar/2018_07/16101622_13-07-2018_Ynternet_BYlteni.pdf

Özer, Y. Y., Komsuoğlu, A., Ateşok Z. Ö. (2016), Türkiye'deki Suriyeli çocukların eğitimi: sorunlar ve çözüm önerileri. Akademik Sosyal Araştırmalar Dergisi, 4(37), 34-42.

Patton, M. Q. (2014). Nitel araştırma ve değerlendirme yöntemleri. (Çev. Mesut Bütün ve Selçuk Beşir Demir). Ankara: Pegem Akademi.

Sakız, H. (2016). Göçmen çocuklar ve okul kültürleri: bir bütünleştirme önerisi. Göç Dergisi, 3(1), 65-81.

Saklan, E., Erginer, A. (2017). Classroom management experiences with syrian refugee students, Education Journal, 6(6), $207-214$.

Sarıtaş, E., Şahin, Ü., Çatalbaş, G. (2016). Illkokullarda yabancı uyruklu öğrencilerle karşılaşılan sorunlar. Pamukkale Üniversitesi Sosyal Bilimler Enstitüsü Dergisi, 25(1), 208-229.

Seydi, A. R. (2014,). Türkiye'nin Suriyeli sığınmacıların eğitim sorununun çözümüne yönelik izlediği politikalar. SDÜ Fen Edebiyat Fakültesi Sosyal Bilimler Dergisi, 31, 267-305.

Suriyeli Çocukların Türk Eğitim Sistemine Entegrasyonunun Desteklenmesi Projesi (pictes). (2017). Erişim adresi: https://pictes.meb.gov.tr/izleme

Taşkın P., Erdemli Sıldıroğlu, Ö. (2016). Problems faced by teachers in the process of Syrian students' education. ECER Leading Education: The Distinct Contributions of Educational Research and Researchers, University College Dublin, Irlanda.

Tösten, R., Toprak, M., Kayan, M. S. (2017). An investigation of forcibly migrated syrian refugee students at turkish public schools. Universal Journal of Educational Research, 5(7), 1149-1160.

United Nations (2016). International migration report 2015 highlights. New York: Department of Economic and Social Affairs. Erişim adresi: http://www.un.org/en/development/desa/population/migration/publications/migrationreport/docs/MigrationReport20 15_Highlights.pdf

Yıldırım, A., Şimşek, H. (2016). Sosyal bilimlerde nitel araştırma yöntemleri. (Genişletilmiş 10. Baskı). Ankara: Seçkin Yayıncılık. 